\title{
PERTUNJUKAN SENDRATARI RAMAYANA: ANTARA TONTONAN DAN TUNTUNAN
}

\section{OLEH:}

\section{Efita Elvandari}

(Dosen FKIP Program Studi Pendidikan Sendratasik Universitas PGRI Palembang)

\begin{abstract}
ABSTRAK
Sendratari Ramayana merupakan bentuk pertunjukan drama tari Jawa yang tidak menggunakan dialog. Dialog dalam pertunjukan sendratari diganti dengan gerak-gerak gestikulasi atau gerak maknawi, terutama dengan sikap-sikap, gerak tangan, dan kepala. Gerak gestikulasi atau gerak maknawi adalah gerak-gerak yang secara visual memiliki makna atau maksud tertentu yang bisa dimengerti dan dipahami oleh orang yang melihatnya. Kajian ini bertujuan untuk memahami pertunjukan sendratari Ramayana yang dipandang sebagai tontonan sekaligus tuntunan bagi masyarakat penikmatnya (penonton), dalam kajian ini akan mengambil objek pertunjukan sendratari Ramayana di Candi Prambanan Yogyakarta. Metode yang digunakan dalam penelitian ini adalah metode deskriptif kualitatif dengan pendekatan kultural, yaitu bertujuan untuk memahami pertunjukan sendratari Ramayana yang dipandang sebagai tontonan sekaligus tuntunan bagi masyarakat penikmatnya (penonton). Dalam pembahasannya akan dipergunakan teori-teori dan pernyataan-pernyataan dari para ahli yang dapat memperkuat pembahasan kajian ini berkaitan dengan pertunjukan sendratari Ramayana sebagai tontonan dan tuntunan bagi masyarakat penikmatnya (penonton).
\end{abstract}

Kata kunci: Sendratari Ramayana, tontonan dan tuntunan

\section{A. PENDAHULUAN}

\section{a) Latar Belakang}

Sendratari Ramayana merupakan bentuk pertunjukan drama tari Jawa yang tidak menggunakan dialog verbal dan mengetengahkan cerita Ramayana. Istilah "sendratari", pertama kali dicetuskan oleh seorang dramawan muda dari Yogyakarta yang bernama (alm) Anjar Asmara pada tahun 1961, ketika drama tari Jawa tanpa dialog verbal ini 
digarap bagi wisatawan mancanegara dan domestik. Dialog dalam pertunjukan sendratari diganti dengan gerak-gerak gestikulasi atau gerak maknawi, terutama dengan sikap-sikap, gerak tangan, dan kepala (Hadi, 1997:46). Gerak gestikulasi atau gerak maknawi adalah gerak-gerak yang secara visual memiliki makna atau maksud tertentu yang bisa dimengerti dan dipahami oleh orang yang melihatnya. Meskipun sendratari tidak menggunakan dialog sebagai media utama penyampaian alur cerita, namun tidak berarti menutup kemungkinan adanya penggunaan dialog, walaupun dialog tersebut tidak berfungsi sebagai penjelas alur cerita. Dengan demikian, sendratari dapat diartikan pula sebagai pertunjukan tari yang membawakan cerita melalui media tari, (Depdikbud, 1981/1982:15).

Sesuai dengan namanya, pertunjukan sendratari Ramayana mengambil alur cerita dari epos Ramayana. Epos Ramayana merupakan cerita yang sangat dikenal bukan saja di Jawa, tetapi di negara-negara Asia, bahkan dikenal oleh sastrawan-sastrawan di seluruh dunia. Ada beberapa versi wiracarita Ramayana di Indonesia yang disajikan dalam berbagai media seni, seperti seni sastra, seni rupa, dan seni pertunjukan (tari, tetaer, film dII), namun demikian sampai sekarang masih sulit untuk melacak versi India yang mana wiracarita Ramayana di Indonesia berasal.

Wiracarita Ramayana yang monumental diperkirakan berkaitan dengan dua suku dari India Utara pada Zaman Veda (sekitar abad X-XII sebelum tarekh masehi), yaitu suku Kosala dan Videha. Di dalam wiracarita tersebut nama keduanya adalah nama-nama kerajaan yang dipersatukan dengan pernikahan antara Rama, yang merupakan pangeran dari Kosala dengan Sinta yang merupakan putri raja Videha, yaitu Janaka. Dari berbagai versi panjang wiracarita Ramayana yang ada, versi tertua diperkirakan ditulis oleh Walmiki, seorang pujangga India (yang diperkirakan) semasa dengan Rama, (Holt, 2000:405). Wiracarita Ramayana India karya Walmiki ditulis kurang lebih pada permulaan tahun Masehi, yang terdiri dari tujuh kandha dan digubah dalam bentuk syair sebanyak 24. 000 sloka yang terbagi menjadi 500 nyanyian, (Haryanto, 1988: 295). Wiracarita Ramayana ini juga diterjemahkan menjadi kitab Ramayana Kakawin yang berbentuk tembang dan dibuat pada masa pemerintahan raja Diah Balitung (820-832 Caka).

Di Indonesia, cerita Ramayana diduga berasal dari abad IX, dan bukti arkeologisnya terpahat pada relief candi Prambanan di Yogyakarta. Adanya bukti bahwa 
cerita Ramayana sudah dipahatkan di candi Prambanan pada abad IX, kemungkinan besar cerita Ramayana sudah diterjemahkan secara lisan dari bahasa Sansekerta ke bahasa Jawa kuna sebelum candi Prambanan didirikan. Cerita Ramayana juga terpahat di dinding candi Penataran di Jawa Timur, yang berasal dari abad XII-XIII, dan diduga merupakan prototipe dari wayang kulit Bali sekarang. Menurut kitab Saridin, pengarang cerita Ramayana Jawa kuna adalah seorang pujangga bernama empu Pujwa pada masa pemerintahan raja Dendrayana dari negara Mamenang. Menurut cerita di Bali, empu Jogiswara yang mengarang kitab tersebut pada tahun 1094 atau 1016 Caka, (Haryanto, 1988:295). Cerita-cerita Ramayana Jawa yang sekarang biasa dipertunjukkan dalam wayang kulit, wayang orang, wayang topeng, Langen Mandra Wanara, serta sendratari, bersumber dari Serat Rama karya Yasadipura, dengan pertimbangan bahwa karya inilah yang paling cocok bagi orang Jawa dan jalan ceritanya tidak terlalu berbelit-belit, namun dalam seni pertunjukan hanya ada tiga versi yang biasa dipergunakan sebagai dasar lakon yaitu Serat Rama, Rama Keling, dan Serat Kandhaning Ringgit Purwa. Ketiganya menggunakan bahasa Jawa baru. Cerita Ramayana versi lain yang berkembang di Indonesia yaitu Kakawin Ramayana, Rama Tantra, Satrugna, Sumarasantaka, Kapiparwa, dan Agyasta, (Soedarsono, 1972:81).

Sendratari Ramayana pada mulanya merupakan gagasan untuk melaksanakan rancangan bangsa, seperti yang tertuang dalam ketetapan MPRS no 1/MPRS/1960 yang menyatakan "bahwa untuk membiayai pembangunan proyek-proyek pemerintah,diperlukan sumber biaya yang berasal dari sektor pariwisata". Salah satu sektor tersebut adalah rencana atau proyek untuk menghidupkan turisme yang akan menambah penghasilan devisa. Pulau Bali pada waktu itu karena dianggap telah penuh dan padat untuk menampung para turis, maka Departemen Perhubungan Darat, Pos Telekomunikasi dan Pariwisata yang pada tahun 1960 dipimpin oleh Menteri Mayor Jenderal TNI G.P.H. Djatikoesoemo, mencari daerah-daerah lain selain Bali yang mampu memikat wisatawan mancanegara dan mungkin dapat dijadikan objek turisme.

Salah satu tempat yang dijadikan proyek turisme tersebut adalah Jawa Tengah (termasuk Daerah Istimewa Yogyakarta) yang dianggap mempunyai ciri-ciri kebudayaan yang khas dan kaya dengan peninggalan-peninggalan kebudayaan yang cukup baik untik 
menarik perhatian para turis. Pada waktu itu mulai dipikirkan pembangunan unit-unit dan penyusunan proyek dalam bidang turisme, diantaranya pembangunan sebuah hotel yaitu Ambarrukmo Palace Hotel (APH) di Yogyakarta, yang lokasinya tidak jauh dari candi Prambanan. Candi Prambanan sebagai daerah tujuan wisata mempunyai arti penting dalam perkembangan seni tari di Indonesia. Di area candi Prambanan inilah kemudian dibangun panggung terbuka Roro Jonggrang, tempat dipertunjukannya sendratari Ramayana.

Pendirian panggung terbuka Roro Jonggrang Prambanan pada tahun 1961 merupakan cetusan gagasan menteri Djatikoesoemo yang diilhami dari perjalanannya ke negara Kamboja. Ketika menyaksikan pertunjukan Ballet Royale du Cambode di depan kuil Angkor Wat Kamboja, menteri Djatikoesoemo mempunyai gagasan untuk membentuk sebuah pergelaran drama tari yang ditampilkan di depan candi Prambanan. Pengalaman menyaksikan pertunjukan di kuil Angkor Wat meyakinkan menteri Djatikoesoemo bahwa pertunjukan di depan candi Prambanan pasti akan sangat memukau. Adapun cerita yang dipilih adalah wiracarita Ramayana, dengan pertimbangan bahwa wiracarita ini terdapat hampir di semua negara di Asia Tenggara. Atas persetujuan presiden Soekarno, pada bulan April 1960 dibangunlah panggung terbuka yang megah di depan candi Prambanan, dengan kapasitas tempat duduk 2000-3000 orang.

Sendratari Ramayana merupakan suatu pertumbuhan kebudayaan dan kesenian yang sangat penting, sehingga seorang seniman Indonesia mengatakan bahwa dengan adanya sendratari Ramayana "Roro Jonggrang", tumbuhlah suatu babak baru dalam kehidupan dan kesenian umumnya serta pada tari dan karawitan khususnya. Pada tanggal 25 Mei 1961, merupakan saat yang bersejarah bagi perkembangan drama tari di Indonesia. Berawal dari sinilah dipentaskannya seni pertunjukan dalam bentuk sendratari yang mengisahkan suatu epos Ramayana dengan media tari dan gamelan yang merupakan suatu ciptaan baru di dunia pementasan seni pertunjukan di Indonesia. Dikemukakan oleh (alm) Anjar Asmara bahwa:

"Melihat pertunjukan sendratari Ramayana berarti menyaksikan kelahiran suatu babak baru di dalam sedjarah seni tari kita, yang merupakan impian dan segala keindahan, demikianlah kesan 
dari pertundjukan ini untuk selama-lamanya sehingga sesuatu yang indah dan menakdjubkan, salah satu punjtak dari kebahagiaan hidup tiap-tiap pentjinta seni", (Anjar Asmara dalam Soeharso, 1970:70).

Keberhasilan produksi sendratari Ramayana di Prambanan ternyata mampu membangkitkan industri pariwisata khususnya di Yogyakarta. Dampak keberhasilan proyek ini bahkan telah melahirkan bentuk-bentuk pertunjukan sendratari Ramayana yang dikemas untuk wisatawan dan disajikan di berbagai tempat, seperti di hotel-hotel, istana/keraton, restoran, dan Tempat Hiburan Rakyat (THR).

Kesenian sebagai salah satu unsur kebudayaan memiliki hubungan yang erat dan tidak bisa lepas dari lingkungan masyarakat pendukung dimana kesenian itu lahir. la tidak mandiri, tapi luluh erat dengan adat setempat, pandangan hidup, tata masyarakat dan agama atau kepercayaan yang secara turun temurun telah diakui keberadaannya oleh masyarakat di lingkungan kesenian itu lahir, (Suharto, 1999:38). Kesenian pada umumnya mempunyai peranan penting dalam kehidupan masyarakat, oleh karena itu kesenian tidak harus dipandang sebagai seni semata tetapi dapat dilihat dari arti dan peranannya. Begitu juga dengan pertunjukan sendratari Ramayana, yang dalam pementasannya selain mempertunjukkan sisi-sisi visualnya/nilai artistik dan estetiknya, juga mengandung maknamakna/nilai-nilai positif yang dapat dijadikan tuntunan bagi penontonnya untuk dapat diterapkan dan diimplementasikan di dalam kehidupan sehari-hari.

\section{b) Rumusan Masalah}

Berdasarkan uraian latar belakang yang telah dikemukakan, dapat diambil rumusan masalah dalam kajian ini, yaitu "Bagaimanakah pertunjukan sendratari Ramayana, dipandang sebagai tontonan dan tuntunan bagi masyarakat pedukungnya/penonton?

\section{c) Tujuan}

Tujuan dalam kajian ini adalah untuk mengetahui dan mendeskripsikan pertunjukan sendratari Ramayana dipandang sebagai tontonan dan tuntunan bagi 
masyarakat pendukungnya/penonton.

\section{d) TINJAUAN PUSTAKA}

Dalam kajian ini, penulis menngunakan beberapa sumber pustaka/sumber tertulis yang bermanfaat untuk mendapatkan data dalam membantu mengupas permasalahan yang dibahas. Sumber-sumber pustaka tersebut antara lain adalah sebagai berikut:

Seni Pertunjukan Indonesia dan Pariwisata, tulisan R.M. Soedarsono (1999), membahas tentang perkembangan pariwisata di Daerah Istimewa Yogyakarta serta awal mula proses terbentuknya grup sendratari Ramayana di candi Prambanan yang merupakan pelopor terbentuknya grup-grup sendratari Ramayana yang lain di Yogyakarta. Buku ini dapat membantu menjelaskan terbentuknya sendratari Ramayana dan perkembangannya.

Pengetahuan Tari, tulisan Wahyudianto (2008), membahas tentang munculnya tari sebagai tontonan/pertunjukan, fungsinya serta klasifikasinya. Buku ini dapat membantu menjelaskan tentang pengertian tari pertunjukan/tari tontonan, fungsi tari tontonan, serta pembagain tari tontonan.

Ramayana Fantasi Audio Animatronik, tulisan I Made Bandem (1995), membahas tentang Nilai-nilai yang terkandung dalam cerita Ramayana, yang ditunjukkan lewat watak-watak tokohnya dan lewat adegan-adegannya. Buku yang isinya serupa adalah Ramayana dalam Lakon Versi Jawa, tulisan Esmiet (1998), menjelaskan tentang ajaran falsafah yang disebut astha brata yang terkandung dalam cerita Ramayana, yaitu ajaran tentang bagaimana seharusnya seseorang memerintah/memimpin sebuah kerajaan atau negara (ajaran kepemimpinan). Buku-buku ini dapat membantu menjelaskan nilai-nilai positif dalam pertunjukan sendratari Ramayana yang dapat diambil hikmahnya dan dijadikan tuntunan bagi masyarakat/penonton.

\section{B.METODE PENELITIAN}

Metode penelitian yang digunakan yakni deskriptif kualitatif, sehingga akan di deskripsikan sesuai dengan hasil analisis data yang telah tersaring yang didapat di lokasi penelitian. Metode deskriptif adalah suatu metode dalam pencarian fakta status kelompok manusia, 
suatu objek, suatu kondisi, suatu sistem pemikiran ataupun suatu peristiwa pada masa sekarang dengan interprestasi yang tepat (Sudarmayanti, dkk., 2002:33).

\section{C.PEMBAHASAN}

Kajian ini bertujuan untuk mengetahui pertunjukan sendratari Ramayana yang dipandang sebagai tontonan sekaligus tuntunan bagi masyarakat penikmatnya (penonton). Dalam pembahasannya akan dipergunakan teori-teori dan pernyataan-pernyataan dari para ahli yang dapat memperkuat pembahasan kajian ini berkaitan dengan pertunjukan sendratari Ramayana sebagai tontonan dan tuntunan bagi masyarakat penikmatnya (penonton).

Perlu diketahu, bahwa hakikat dari seni tontonan adalah bahwa di sana ada dua pihak yang peranannya berbeda yaitu yang ditonton dan yang menonton. Dalam tari pertunjukan/ tontonan, pihak yang ditonton adalah penari, dan yang menonton adalah yang memperhatikannya (Sumaryono dan Suanda, 2002:1). Tari tontonan dipertunjukkan dalam berbagai konteks sosial, tidak saja dalam bentuknya yang sederhana sebagaimana terjadi di ruang kelusrga, melainkan di berbagai forum sosial seperti hiburan umum, ritual, festival, propaganda produk, dan kampanye politik. Tempat pertunjukannya bisa di gedung, pertunjukan, di pendhopo, di halaman rumah, di pasar, di lapangan terbuka, dan di atas kapal. Tari tontonan tumbuh terus dalam berbagai bentuk gaya sampai sekarang, baik dari sisi teknik gerak, komposisi, pemanggungan dan lain-lain. Tari tontonan mempunyai dua fungsi yaitu fungsi estetis dan fungsi seremonial. (Wahyudianto, 2008:8485).

Fungsi tari pertunjukan estetis dapat dijumpai di arena festival-festival, ajang kreatif pentas seni, pentas prestasi, dan pentas-pentas sejenis, sehingga tari dalam perspektif ini memang dibutuhkan untuk mendapatkan apresiasi maksimal tentang kedudukan esensi nilai seni dalam tari. Kaidah-kaidah ilmu penciptaan tari, bentuk, teknik, estetiknya dan seluruh aspek pertunjukan tari dijadikan orientasi penilaian sehingga tari dalam kebutuhan ini dihadirkan untuk kebutuhan estetik. Penontonnya spesifik yang digolongkan sebagai para penghayat seni, karenanya kalau dilihat dari sisi fungsinya maka 
tari dalam kebutuhan ini adalah fungsi estetik. Jadi fungsi utamanya "primer" adalah untuk mendapatkan capaian estetik yang maksimal. Tarian tontonan dalam fungsi ini lebih serius karena dipergelarkan untuk acara tertentu dan ditonton untuk kalangan tertentu. Meskipun bukan untuk upacara, namun kriteria tari untuk tontonan ini juga menuntut sikap serius penonton saat menyaksikan pertunjukan, misalnya contoh yang paling mudah adalah ketika pergelaran sebuah karya koreografi untuk ujian kenaikan tingkat di sekolah kejuruan tari. Tontonan ini diketegorikan serius karena tujuannya bukan semata-mata untuk hiburan, tetapi lebih kepada penanaman apresiasi seni serta penggalian kreatifitas dari para siswa di sekolah yang bersangkutan (Pamadhi dkk, 2008: 9.21).

Fungsi tari pertunjukan seremonial; sangat mungkin materi tari pertunjukan ini sama dengan pertunjukan estetis tetapi karena momen atau event kegiatannya bukan untuk hayatan estetik maka fungsinya juga berbeda. Dalam kaitan ini tari seperti yang dipertunjukkan pada acara upacara tujuh belasan (hari kemerdekaan RI), upacara pembukaan Pekan Olahraga, penutupan sebuah acara konferensi-konferensi, hajatan pengantin dan sejenisnya; maka fungsi tarian ini digolongkan ke dalam fungsi sosial, itulah fungsi primer tari seremonial.

Sendratari Ramayana Prambanan sebagai sajian yang dipentaskan untuk para wisatawan baik domestik maupun asing maka, dalam pertunjukannya sangat memperhatikan segi-segi artistik dan estetik dalam elemen-elemen pementasannya, baik dari segi kostum, tata rias, gerak, pola lantai, seting dan properti, tata suara, serta tata cahaya yang cukup menarik dan variatif, sehingga sendratari Ramayana ini akan menjadi sebuah produk seni tontonan yang akan menjadi salah satu alternatif hiburan bagi mesyarakat (penonton).

Disamping dua fungsi tari pertunjukan/tari tontonan di atas, dalam pertunjukan sendratari Ramayana terkandung nilai-nilai positif yang dapat diambil hikmahnya oleh masyarakat sebagai tuntunan hidup bagi mereka. Fungsi tuntunan disini lebih menyentuh pada misi yang secara verbal diungkapkan. Pelaku seni, dalam hal ini lebih dituntut untuk menyampaikan pesan moral yang akan dicapai. Misalnya seorang dalang harus mampu memerankan semua tokoh yang ada di dalam kotak wayangnya. Dalang harus mampu 
membawakan diri dan memilah mana tokoh simbol angkara murka dan mana tokoh simbol kebaikan. Dimensi inilah yang mewarnai tuntunan dibalik sebuah tontonan.

Cerita Ramayana yang telah digubah oleh pujangga Yasadipura ke dalam Serat Rama, merupakan bentuk karya sastra yang di dalamnya memuat ensiklopedi kehidupan yang merupakan refleksi dari aspek ritual dan moral tentang hidup dan kelakuan manusia baik dalam kapasitas sebagai makhluk pribadi maupun makhluk sosial (Hersapandi, 1987:2). Selain simbol-simbol bermakna yang ditampilkan, sendratari Ramayana juga memiliki kandungan nilai yang beragam. Nilai yaitu sifat-sifat atau hal-hal yang penting dan berguna bagi kemanusiaan (Depdikbud, 1991:690). Setiap seni memiliki nilai-nilai dasar

yang sama, yaitu mencakup nilai penampilan (appearance), berupa aspek-aspek yang dapat dilihat secara fisik misalnya, keindahan kostum penarinya, kemegahan seting pertunjukannya, kecantikan/ketampanan penarinya, keluwesan dan kelenturan gerak penarinya dll; nilai isi (content), berupa aspek kognisi (pengetahuan), nilai rasa, nilai moral, nilai religi dan nilai moral; serta nilai pengungkapan (presentation), yang bisa berupa kemampuan pelaku seni (penari) dalam membawakan sebuah peran/penokohan (wirasa), kemampuan mengolah tubuh dalam bergerak sesuai kebutuhan peran (wiraga), kemampuan menyesuaikan antara gerak, penghayatan dengan musik pengiringnya (wirama).

Dalam pertunjukan sendratari Ramayana, ada beberapa nilai positif yang dapat dijadikan tuntunan/teladan, yang digambarkan melalui tokoh-tokohnya, (Bandem, 1995:89) yaitu:

1. Kebesaran dan ketulusan hati Rama meninggalkan istana karena janji ayahnya kepada ibu tirinya, meskipun sebenarnya dia dapat menikmati gemerlapnya tahta kerajaan. Demi menghormati janji ayahnya kepada ibu tirinya, dia rela diasingkan ke hutan selama 12 tahun.

2. Kebesaran hati Dewi Shinta dapat dijadikan teladan dalam hubungan rumah tangga/keluarga. Dia tidak pernah bersikeras mempengaruhi Rama akan haknya sebagai putra mahkota, sebaliknya dia bersikeras supaya bisa menemani Rama ke hutan.

3. Tokoh Lesmana dapat dijadikan teladan bakti seorang saudara dalam keluarga. Sebagai saudara lebih muda, dia merasa tidak pantas tinggal dan menikmati kesenangan di istana 
sementa saudara tertuanya hidup di hutan, sehingga memilih mengikuti saudaranya ke hutan.

Pada beberapa penggalan cerita Ramayana, juga memuat nilai-nilai positif seperti nilai kemanusiaan, kebaikan, kesetiaan, dan cinta kasih, yaitu:

1. Penggambaran rasa cinta kasih terhadap sesama, ditunjukkan dalam adegan dimana Shinta dengan tulus menolong pengemis tua jelmaan Rahwana.

2. Penggambaran rasa kemanusiaan, ditunjukkan dalam adegan pada saat Jatayu dengan gagah berani mengorbankan nyawanya demi menyelamatkan Shinta dari kejahatan Rahwana.

3. Penggambaran sifat pemaaf dan kebesaran hati, ditunjukkan dalam adegan ketika saudara kembarnya menemui ajalnya, Sugriwa dengan tulus memaafkan kesalahan saudaranya yang telah menghianatinya bahkan bersedia menjaga anak dan istri dari saudaranya tersebut.

4. Penggambaran sifat pemberani, ditunjukkan dalam adegan ketika Kumbakarna melawan kakaknya (Rahwana) karena menolong utusan Rama yang merupakan musuh kakaknya, sehingga dia diusir dari Alengka.

5. Penggambaran sifat cinta/membela tanah air, ditunjukkan dalam adegan ketika Kumbakarna menghentikan tapanya karena diutus kakaknya, Rahwana untuk bertempur menghadapi pasukan Rama, walaupun dia tahu bahwa kakaknyalah yang bersalah, tetapi demi tanah airnya dia rela mengorbankan nyawanya.

6. Penggambaran sifat kesetiaan, ditunjukkan dalam adegan ketika Rama meragukan kesucian Shinta, Shinta rela dibakar tubuhnya untuk membuktikan bahwa dirinya masih suci dan tidak mengkhianati Rama.

Dalam sendratari Ramayana juga terdapat suatu ajaran falsafah yang disebut dengan astha brata, yaitu ajaran tentang bagaimana seharusnya seseorang memerintah sebuah kerajaan atau negara (ajaran kepemimpinan), yang terdiri dari delapan ajaran (Esmiet, 1998:84-88), yaitu:

1. Berwatak air: memberikan obat bagi yang kehausan, baik haus air, haus ilmu pengetahuan, maupun haus kesejahteraan. Jujur, karena air tidak pernah mengatakan pahit jika berisi gula dan tidak pernah menyebarkan bau jika di tubuhnya berisi bunga. Bersih, karena pada hakekatnya air tidak berbau, tidak berwarna, dan tidak berbentuk. 
Berwibawa, karena air memberikan rasa sejuk, memberi keadilan, berpihak kepada yang lemah, dan tidak pernah memilih-milih.

2. Berwatak api: pemberi semangat, pemberi kekuatan, dan penghukum. Seorang pemimpin harus pandai memberikan semangat kepada rakyatnya agar bisa berdiri di kala jatuh dan sabar di kala sakit. Seorang pemimpin harus tegas bertindak, menentukan sikap adil. Jika yang dibakar kalangan bawah, maka semuanya harus terbakar, namun jika yang terbakar sebelah atas, api tidak akan turun ke bawah untuk membakar yang ada di bawah. 3. Berwatak angin: menciptakan rasa sejuk, memberikan rasa dingin. Seorang pemimpin harus bisa menciptakan rasa selalu dibutuhkan, selalu memperhatikan celah-celah kosong, bisa menempatkan diri dimanapun dia berada, selalu ada jika dibutuhkan.

4. Berwatak bumi: bumi bisa mewadahi apapun, yang baik dan yang buruk diterimanya dengan ikhlas. Seorang pemimpin harus menerima apa saja yang diberikan rakyatnya dengan ikhlas, yang buruk bisa dijadikan pelajaran dan diolah agar bisa bermanfaat, yang baik dilestarikan dan ditingkatka, tidak pongah jika mendapat pujian, tidak marah jika mendapat kritikan.

5. Berwatak langit: melindungi dan memayungi, pandangannya tidak sempit, banyak pengetahuan tentang hidup dan kehidupan, tidak mudah menerima pemberitaan yang bersifat "menyenangkan pemimpin",

6. Berwatak matahari: pemberi panas, memberikan energi, dan memberikan penerangan. Meskipun matahari sangat berkuasa, namun untuk malam hari kekuasaan diserahkan sepenuhnya kepada bulan dan bintang. Seorang pemimpin hendaknya jangan memegang kekuasaan sendiri, namun memberi kepercayaan kepada anak buahnya agar mekanisme kepemimpinan tidak timpang.

7. Berwatak rembulan: angker namun tidak menakutkan, lugas, pendangannya penuh kasih sayang, tidak ditakuti namun disegani. Mendahulukan kemakmuran rakyat sebelum kemakmuran dirinya, mendahulukan kesejahteraan rakyatnya sebelum kenikmatannya.

8. Berwatak bintang; memberikan harapan-harapan baik kepada rakyatnya, rendah hati, tidak suka menonjolkan diri, harus mengakui adanya kelebihan-kelebihan orang lain. 


\section{D.SIMPULAN}

Sendratari Ramayana merupakan bentuk pertunjukan drama tari Jawa yang tidak menggunakan dialog Dialog dalam pertunjukan sendratari diganti dengan gerak-gerak gestikulasi atau gerak maknawi, terutama dengan sikap-sikap, gerak tangan, dan kepala. Gerak gestikulasi atau gerak maknawi adalah gerak-gerak yang secara visual memiliki makna atau maksud tertentu yang bisa dimengerti dan dipahami oleh orang yang melihatnya. Kajian ini bertujuan untuk memahami pertunjukan sendratari Ramayana yang dipandang sebagai tontonan sekaligus tuntunan bagi masyarakat penikmatnya (penonton), dalam kajian ini akan mengambil objek pertunjukan sendratari Ramayana di Candi Prambanan Yogyakarta.

Sendratari Ramayana Prambanan sebagai sajian yang dipentaskan untuk para wisatawan baik domestik maupun asing maka, dalam pertunjukannya sangat memperhatikan segi-segi artistik dan estetik dalam elemen-elemen pementasannya, baik dari segi kostum, tata rias, gerak, pola lantai, seting dan properti, tata suara, serta tata cahaya yang cukup menarik dan variatif, sehingga sendratari Ramayana ini akan menjadi sebuah produk seni tontonan yang akan menjadi salah satu alternatif hiburan bagi mesyarakat (penonton).

Disamping dua fungsi tari pertunjukan/tari tontonan di atas, dalam pertunjukan sendratari Ramayana terkandung nilai-nilai positif yang dapat diambil hikmahnya oleh masyarakat sebagai tuntunan hidup bagi mereka. Fungsi tuntunan disini lebih menyentuh pada misi yang secara verbal diungkapkan. Pelaku seni, dalam hal ini lebih dituntut untuk menyampaikan pesan moral yang akan dicapai. 


\section{DAFTAR PUSTAKA}

Bandem, I Made. 1995. Ramayana Fantasi Audio Animatronik. Denpasar: STSI Denpasar

Depdikbud. 1981/1982. Khasanah Tari Daerah 1. Jakarta: Proyek Pengadaan buku SPG/SGPLB

Depdikbud. 1991. Kamus Besar Bahasa Indonesia. Jakarta: Balai Pustaka

Esmiet. 1998. "Ramayana dalam Lakon versi Jawa: dalam Sarwono Suprapto dan Sri Hasti Widiastuti (ed), Ramayana: Transformasi Pengembangan dan masa depannya. Yogyakarta: Lembaga Studi Jawa Yogyakarta

Hadi, Y. Sumandiyo. 1997. "Perkembangan Ragam Gerak Tari dalam Festival Sendratari Gaya Yogyakarta" dalam Fred Wibowo (ed) Gagasan-gagasan dalam Sendratari Gaya Yogyakarta. Yogyakarta: Yayasan untuk Indonesia

Haryanto, S. 1988. Pratiwimba Adiluhung: Sejarah dan Perkembangan Wayang. Jakarta: Djambatan

Hersapandi. 1986. Tinjauan Struktur Dramatik Sendratari Ramayana Prambanan. Yogyakarta: Institut Seni Indonesia ( ISI) Yogyakarta

Holt, Claire. 2000. Melacak Jejak Perkembangan Seni di Indonesia. Bandung: Masyarakat Seni Pertunjukan Indonesia (MSPI)

Soedarsono, R.M. 1972. Djawa dan Bali: Dua Pusat Perkembangan Tari Tradisionil di Indonesia. Yogyakarta: Gadjah Mada University Press

Soeharso. 1970. "Sendratari Ramayana Rarajonggrang" dalam Laporan Seminar Sendratari Ramayana Nasional. Yogyakarta: Panitia Penyelenggara

Sumaryono dan Endo Suanda. 2002. Tari Tontonan. Jakarta: Lembaga Pendidikan Seni Nusantara

Suharto, Ben. 1999. Tayub: Pertunjukan dan Ritus Kesuburan. Bandung: Masyarakat Seni Pertunjukan Indonesia (MSPI)

Wahyudianto. 2008. Pengetahuan Tari. Surakarta: ISI Press 